\title{
ANALISA LETAK DINDING GESER (SHEAR WALL) TERHADAP PERILAKU STRUKTUR GEDUNG AKIBAT BEBAN GEMPA
}

\author{
Nurul Anggraini Usmat I., Imran Imran., Mufti A. Sultan \\ ${ }_{1}^{1}$ Program Studi Teknik Sipil, Universitas Khairun, Ternate \\ email :anggraininl@gmail.com,Imran.imo@unkhair.ac.id,muftiasltn@unkhair.ac.id \\ Manuscript recieved:03-11-2019 Revision Accepted: 21-11-2019
}

\begin{abstract}
Abstrak
Wilayah kota ternate pada peta gempa SNI 1726-2012 berada pada zona dengan pecepatan 0,4-0,5 g (PGA, MCEG) dan percepatan 1,0 -1,2 g (SS, MCER) dengan frekuensi aktivitas seismik yang tinggi. Untuk itu pada setiap desain struktur bangunan di kota Ternate wajib untuk memperhitungkan gaya gempa pada beban rencana. Memasang shear wall (SW) pada struktur gedung sebagai Sistem Ganda Rangka Pemikul Momen Khusus merupakan solusi untuk menahan gaya lateral gempa. Penelitian ini mengkaji posisi yang optimum untuk penempatan SW pada gedung yang menerima beban gempa statik dan dinamik. Gedung yang ditinjau adalah gedung bertingkat 6 lantai memiliki panjang $45 \mathrm{~m}$ dan lebar $25 \mathrm{~m}$ dengan tinggi tiap lantai $5 \mathrm{~m}$. Penempatan SW menggunakan 4 variasi layout. Hasil penelitian menunjukkan bahwa layout-2 adalah mode penempatan yang terbaik untuk penempatan SW pada struktur gedung sistem ganda dan SRPMK.
\end{abstract}

Kata kunci: shear wall, gempa, sistem ganda

\section{PENDAHULUAN}

Wilayah kota Ternate pada peta gempa SNI 1726-2012 berada pada zona dengan pecepatan 0,4-0,5 g (PGA, MCEG) dan percepatan 1,0-1,2 g (SS, MCER) dengan frekuensi aktivitas seismik yang cukup tinggi. Beberapa tahun terakhir telah terjadi gempa bumi yang mengguncang Kota Ternate, yaitu gempa berkekuatan 7,3 skala ricther (SR) pada 15 November 2014, kemudaian pada 25 Januari 2015 berkekuatan 5,4 SR, pada 8 Juni 2016 berkekuatan 6,6 SR, pada tahun 2019 terjadi gempa sebesar 7,1 SR. Pada tahun 2019 terjadi gempa yang menimbulkan korban jiwa yaitu pada tanggal 9 juli dengan kekuatan 7,1 SR, gempat dengan kekuatan 7,1 SR berpotensi tsunami karena terjadi pada kedalaman $<10 \mathrm{~m}$ di dasar laut kemudian pada tanggal 14 Juli dengan kekuatan sebesar 7,2 SR serta masih banyak lagi gempa-gempa yang telah terjadi (Sumber: Berita BMKG). Gempa yang terjadi bisa mengakibatkan kerusakan pada struktur gedung maupun non-gedung. Untuk mengantisipasi resiko dan dampak bencana yang terjadi akibat gempa bumi maka diperlukan konstruksi bangunan tahan gempa untuk menjamin keselamatan pengguna bangunan terhadap gempa yang mungkin terjadi serta menghindari dan meminimalisir kerusakan struktur bangunan dan korban jiwa akibat gempa.

Semakin tinggi bangunan gedung, semakin rentan pula bangunan tersebut merespon beban lateral, terutama beban gempa. Oleh karena itu diperlukan sistem struktur khusus untuk menahan beban lateral pada bangunan gedung bertingkat, salah satunya yaitu dengan dinding geser (shear wall). Penambahan dinding geser sangat berpengaruh pada pembangunan gedung bertingkat selain untuk mencegah kegagalan dinding eksterior, 
dinding geser juga mendukung beberapa lantai gedung dan memastikan tidak terjadinya keruntuhan yang disebabkan oleh gaya lateral akibat beban gempa.

Lokasi penempatan dinding geser juga sangat berpengaruh terhadap perilaku gedung bertingkat dalam merespon beban gempa. Ketika dinding geser ditempatkan pada lokasilokasi tertentu yang cocok dan strategis, dinding tersebut dapat digunakan secara ekonomis untuk menyediakan tahanan beban horisontal yang diperlukan, oleh karenanya sangat penting untuk menentukan lokasi dinding geser yang efektif, efisien, dan ideal. Beberapa penelitian tentang penempatan atau layout dinding geser dalam suatu struktur bangunan antara lain. Penempatan letak dinding geser dalam struktur bangunan pada sisi gedung paling pinggir menghasilkan kekakuan struktur yang lebih besar dibandingkan apabila diletakkan di dalam struktur, hasil ini diperoleh berdasarkan 7 jenis uji model penempatan dinding geser dalam struktur bangunan 12 lantai (Andalas, Suyadi, \& Husni, 2016). Struktur dinding geser dengan pola IV menghasilkan waktu getar alami 1,66 sekon dan memenuhi persyaratan UBC 1997 (Astuti, 2016). Pemodelan dinding geser dengan 4 tipe model pada struktur bangunan berlantai 10, menghasilkan model dinding geser berbentuk L memberikan respon terhadap gempa lebih baik dibandingan model I yang digunakan (Kusuma, 2018). Pemodelan pada struktur apartemen 34 lantai dengan variasi penempatan dinding geser. Penempatan dan variasi bentuk dinding geser yang berbeda dapat mempengaruhi kekakuan struktur terhadap beban lateral yang diterima (Hasan \& Astira, 2013). Pemodelan bangunan Gedung bertingkat 25 pada wilayah Manado menyatakan bahwa respons dinamik suatu bangunan bertingkat banyak, dalam hal ini simpangan horisontal, dipengaruhi oleh berbagai faktor, salah satunya adalah tata letak dinding geser. Dinding geser yang diposisikan mendekati pusat massa suatu bangunan, baik sumbu $\mathrm{x}$ maupun sumbu $\mathrm{y}$ dalam arah ortogonal, menghasilkan nilai simpangan horisontal yang lebih kecil dibandingkan dinding geser yang diposisikan menjauhi pusat massa bangunan tersebut (Majore, Wallah, \& Dapas, 2015). Pemodelan letak dinding geser dalam bangunan gedung tidak beraturan menghasilkan tingkat efesiensi model D disebabkan simpangan yang dihasilkan lebih kecil dibandingkan model yang lain (Baehaki, Kuncoro, \& Dahlia, 2019).

Beberapa penelitian pemodelan bangunan yang ada di wilayah Ternate antara lain : Pemodelan bangunan struktur bangunan atau gedung beton bertulang dengan metode pushover, disimpulkan bahwa kinerja komponen atau elemen struktur dalam keadaan aman dimana $\delta t_{\max }<\delta t$ serta skema distribusi sendi plastis tidak memperlihatkan komponen struktur yang melewati kinerja IO (Mangoda, Sultan, \& Imran, 2019). Pemodelan bangunan Gedung di Ternate dengan menggunakan metode pushover menunjukkan bahwa konsep kolom kuat balok lemah pada struktur yang ditinjau, telah memenuhi (Sultan, 2017).

\section{LANDASAN TEORI}

\section{Dinding Geser}

Dinding geser atau shear wall adalah dinding struktural berbahan beton bertulang massif yang dirancang untuk menahan geser dan gaya lateral akibat gempa. Dinding geser harus dirancang sedemikian rupa sehingga memiliki kekakuan memadai yang diperlukan untuk mengurangi simpangan antar lantai yang disebabkan oleh beban lateral seperti gempa.

Dinding geser membentang pada seluruh jarak vertikal antar lantai mulai dari pondasi sampai ke bagian top bangunan. Kesalahan atau ketidakcermatan dalam penempatan posisi 
dinding geser dapat menimbulkan suatu kondisi dimana pusat massa dan pusat elemen penahan struktur tidak tepat pada satu lokasi yang sama, sehingga menimbulkan gaya puntir yang mengakibatkan gedung berotasi di sekeliling pusat elemen penahan, dan kondisi ini menyebabkan banyak gedung mengalami kerusakan baik secara struktural maupun nonstruktural.

Dinding geser atau shear wall dapat dibangun pada sisi luar bangunan maupun sisi dalam bangunan, tanpa adanya batasan geometris dari dinding geser itu sendiri. Sistem dinding geser dibagi menjadi dua bagian, yaitu sistem terbuka dan sistem tertutup (Schueller, 1977). Dinding geser di sisi luar bangunan ataupun dalam bangunan dapat diposisikan secara simetris maupun tak simetris. Berdasarkan letak dan fungsinya, dinding geser dibagi menjadi 3 jenis, yaitu:

1. Bearing Walls adalah dinding geser yang juga mendukung sebagian besar dari beban gravitasi

2. Frame Walls adalah dinding geser yang menahan beban lateral, dimana beban gravitasi berasal dari frame beton bertulang

3. Core Walls adalah dinding geser yang terletak di wilayah dalam gedung dan biasanya digunakan untuk transportasi vertikal.

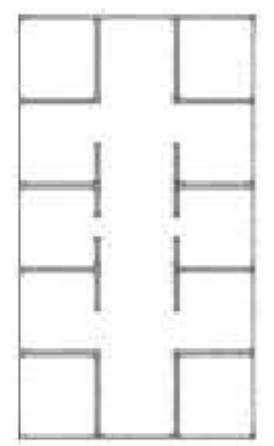

(a) Bearing Walls

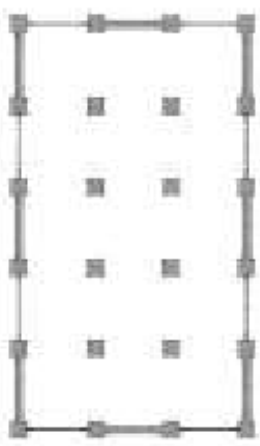

(b) Frame Walls

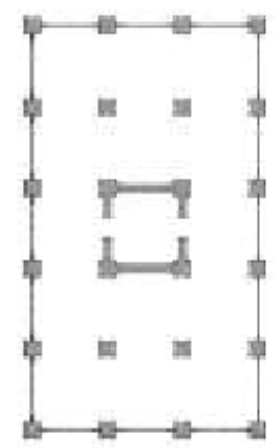

(c) Core Walls

Gambar 1. Jenis shear wall berdasarkan letak dan fungsinya

\section{Pembebanan Struktur}

Berdasarkan SNI 1727-2013 dan SNI 1726-2012, komponen struktur gedung harus direncanakan kekuatannya terhadap beban-beban berikut:

1. Beban mati adalah berat dari semua bagian suatu gedung yang bersifat tetap, termasuk segala unsur tambahan, penyelesaian-penyelesain, mesin-mesin, serta peralatanperalatan tetap yang merupakan bagian yang tak terpisahkan dari gedung itu. Beban mati yang diperhitungkan dalam struktur gedung ini merupakan berat sendiri elemen struktur bangunan yang memiliki fungsi struktural menahan beban dan beban mati tambahan yang bersifat tetap

2. Beban hidup adalah semua beban yang terjadi akibat penghunian atau penggunaan gedung dan di dalamnya termasuk beban-beban pada lantai yang berasal dari barangbarang yang dapat berpindah sehingga dapat mengakibatkan perubahan lantai atau atap

3. Beban gempa adalah beban yang timbul akibat percepatan getaran tanah pada saat gempa terjadi. Beban gempa dapat dilakukan dengan analisis gaya lateral ekuivalen, analisis respon spektrum dan prosedur riwayat respon seismik. 


\section{Kontrol Struktur}

Analisa struktur dari simulasi kombinasi pembebanan dikontrol terhadap parameter berikut

1. Waktu Getar Alami

Perioda getar struktur, $T$ atau $T_{c}$, dalam arah yang ditinjau harus diperoleh menggunakan properti struktur dan karateristik deformasi elemen penahan dalam analisis yang teruji. Perioda fundamental struktur, $T$ atau $T^{c}$, tidak boleh melebihi hasil koefisien untuk batasan atas pada perioda yang dihitung $\left(C_{u}\right)$ dan perioda fundamental pendekatan, $T_{a}$, ditentukan. Sebagai alternatif pada pelaksanaan analisis untuk menentukan perioda fundamental struktur, $T$, diijinkan secara langsung menggunakan perioda bangunan pendekatan, $T_{a}$. Maka persyaratan dan perhitungan tersebut dapat dinyatakan seperti berikut:

Perioda fundamental maksimum ( $\left.T_{\text {maks }}\right)$ :

$T_{\text {maks }}=C_{t} . T_{a} \quad C_{t}=$ nilai parameter perioda pendekatan

Persyaratan perioda fundamental $(T)$

$T_{c}<T_{m a k s}$

2. Partisipasi Massa

Analisis jumlah ragam harus dilakukan untuk menentukan ragam getar alami untuk struktur. Analisis harus menyertakan jumlah ragam yang cukup untuk mendapatkan partisipasi massa ragam terkombinasi sebesar paling sedikit $90 \%$ dari massa aktual dalam masing-masing arah horisontal ortogonal dari respons yang ditinjau oleh model

3. Gaya Geser Dasar (V)

Bila perioda fundamental yang dihitung melebihi $C_{u}{ }^{*} T_{a}$, maka $C_{u}{ }^{*} T_{a}$ harus digunakan sebagai pengganti dari $T$ dalam arah itu. Kombinasi respons untuk geser dasar ragam $\left(V_{t}\right)$ lebih kecil $85 \%$ dari geser dasar yang dihitung $(V)$ menggunakan prosedur gaya lateral ekivalen, maka gaya harus dikalikan dengan $\left(0,85 \mathrm{~V} / \mathrm{V}_{t}\right)$

4. Simpangan Struktur

Penentuan simpangan antar lantai tingkat desain $(\Delta)$ harus dihitung sebagai perbedaan defleksi pada pusat massa ditingkat teratas dan terbawah yang ditinjau. Apabila pusat massa tidak terletak segaris dalam arah vertikal, diijinkan untuk menghitung defleksi di dasar tingkat berdasarkan proyeksi vertikal dari pusat massa tingkat diatasnya

5. Kontrol Sistem Struktur

Untuk sistem ganda, rangka pemikul momen harus mampu menahan paling sedikit $25 \%$ gaya gempa desain. Tahanan gaya gempa total harus disediakan oleh kombinasi rangka pemikul momen dan dinding geser atau rangka bresing, dengan distribusi yang proporsional terhadap kekakuannya.

\section{METODOLOGI}

\section{Parameter Analisis}

Tahapan analisis secara rinci, dimulai dari studi literatur, menentukan lokasi dan data gedung, desain variasi letak shear wall, pemodelan dan analisa struktur dengan menggunakan program komputer. Parameter input pada tabel berikut: 
Tabel 1. Data gempa untuk strktur gedung

\begin{tabular}{|c|c|c|c|}
\hline No & Label & Hasil & Keterangan \\
\hline 1 & Fungsi bangunan & Perkantoran & - \\
\hline 2 & Lokasi & Kota Ternate & - \\
\hline 3 & Kategori resiko bangunan & II & SNI Tabel 1 \\
\hline 4 & Faktor keutamaan (Ie) & 1 & SNI Tabel 2 \\
\hline 5 & Tanah dasar & Tanah sedang & - \\
\hline 6 & Nila $S_{D 1}$ & 0,512 & SNI/Puskim \\
\hline 7 & Nilai $S_{D S}$ & 0,771 & SNI/Puskim \\
\hline 8 & Nilai Ca & 0,308 & SNI/Puskim \\
\hline 9 & Nilai Cv & 0,512 & SNI/Puskim \\
\hline \multirow[t]{2}{*}{10} & \multirow[t]{2}{*}{ Faktor modifikasi respons (R) } & 8 (SRPMK) & \multirow[t]{2}{*}{ SNI Tabel 9} \\
\hline & & 7 (sistem ganda) & \\
\hline 11 & Faktor pembesaran defleksi (Cd) & 5,5 & SNI Tabel 9 \\
\hline 12 & Koefisien $\mathrm{Cu}$ & 1,4 & SNI Tabel 14 \\
\hline \multirow[t]{2}{*}{13} & \multirow[t]{2}{*}{ Nilai Ct dan $x$} & 0,$0466 ; 0,9$ (SRPMK) & \multirow[t]{2}{*}{ SNI Tabel 15} \\
\hline & & 0,$0488 ; 0,75$ (sistem ganda) & \\
\hline 14 & Simpangan antara lantai izin $(\Delta \mathrm{\alpha})$ & $0,020 h_{s x}$ & SNI Tabel 16 \\
\hline
\end{tabular}

\section{Pemodelan Geometrik Gedung}

1. Properti Gedung

Fungsi gedung

Panjang gedung

Lebar gedung

Jumlah lantai

Tinggi gedung

Jenis Struktur

Sistem penahan gempa

2. Material Propertis

Berat isi beton ( $\square$ )

Modulus elastisitas beton $\left(E_{c}\right)$

Angka poison beton ( $\square$ )

Kuat tekan beton $\left(f^{\prime}\right)$

Berat is baja ( $\square$ s)

Modulus elastisitas baja $\left(E_{s}\right)$

Tegangan leleh tulangan utama $\left(f_{y}\right)$

Tegangan putus tulangan utama $\left(f_{u}\right)$

Tegangan leleh tulangan sengkang $\left(f_{y s}\right)$

Tegangan putus tulangan sengkang $\left(f_{u s}\right)$
: Kantor

:45 meter@5 meter

: 25 meter@5 meter

: 6 lantai

:30 meter@5 meter

: Rangka beton bertulang

: SRPMK dan Sistem Ganda

3. Dimensi Elemen Struktur

Tabel 2. Komponen Struktur Gedung

\begin{tabular}{cll}
\hline No & \multicolumn{1}{c}{ Elemen } & \multicolumn{1}{c}{ Dimensi $\mathbf{( m m )}$} \\
\hline $\mathbf{1}$ & Pelat Atap & 100 \\
\hline $\mathbf{2}$ & Pelat Lantai 1 - Lantai 5 & 120 \\
\hline $\mathbf{3}$ & Balok & $300 \times 450$ \\
\hline $\mathbf{4}$ & Kolom & $450 \times 450$ \\
\hline $\mathbf{5}$ & Dinding Geser & 250 \\
\hline
\end{tabular}


4. Geometrik Gedung

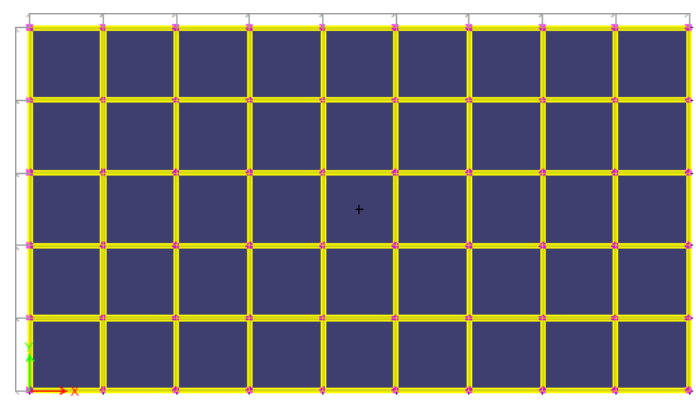

(a) Denah lantai tipikal

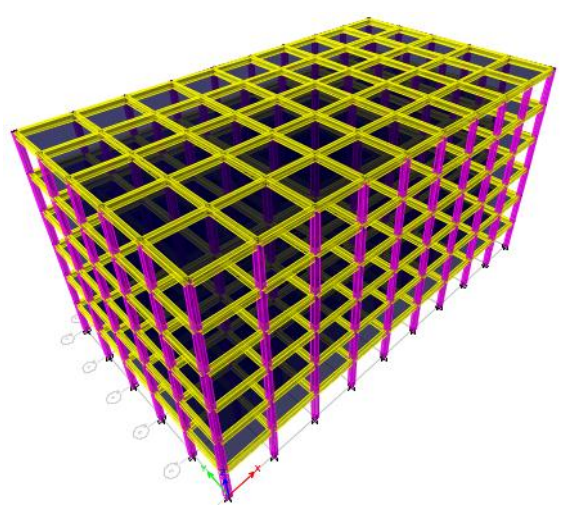

(b) Perpespektif 3D

Gambar 2. Pemodelan geometrik struktur gedung

5. Variasi Letak Dinding Geser

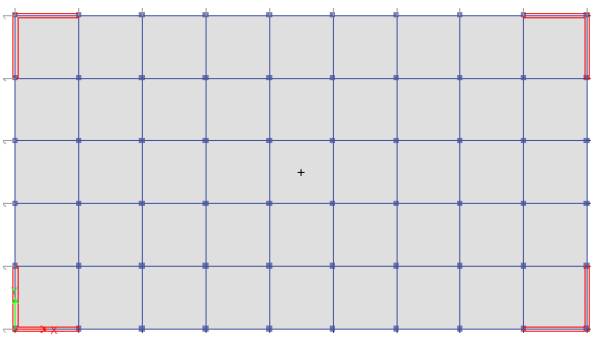

(a) layout-1 (simetris sisi terluar)

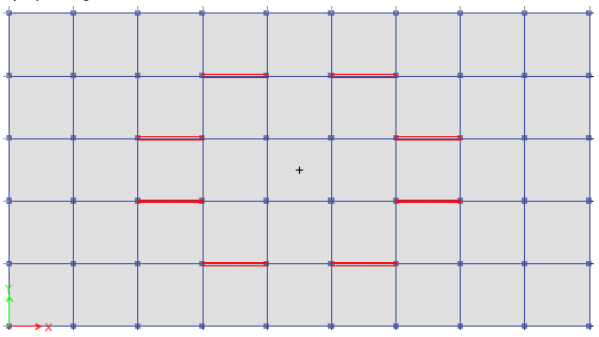

(c) layout-3 (simetris di sumbu kuat)

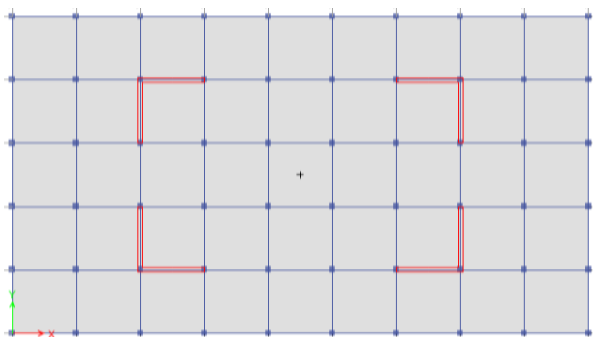

(b) layout-2 (simetris dekat pusat massa)

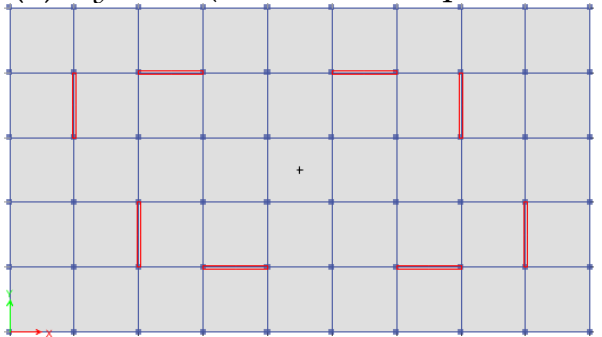

(d) layout-4 (asimetris bagian dalam)

Gambar 3. Variasi penempatan dinding geser untuk sistem ganda

\section{HASIL DAN PEMBAHASAN}

\section{Waktu Getar Struktur (T)}

Perbandingan waktu getar struktur antar model ditunjukkan pada Tabel 3 berikut:

Tabel 3. Perbandingan Waktu Getar Struktur

\begin{tabular}{lccccc}
\hline $\begin{array}{c}\text { Waktu Getar } \\
\text { (detik) }\end{array}$ & SRPMK & Layout-1 & Layout-2 & Layout-3 & Layout-4 \\
\hline $\mathbf{T}_{\mathbf{a}}$ min & 0,814 & 0,529 & 0,529 & 0,529 & 0,529 \\
\hline $\mathbf{T}_{\mathbf{a}} \mathbf{m a x}$ & 1.1396 & 0,741 & 0,741 & 0,741 & 0,741 \\
\hline $\mathbf{T}_{\mathbf{c}} \mathbf{- x}$ & 1.216 & 0,549 & 0,536 & 0,488 & 0,625 \\
\hline
\end{tabular}




\begin{tabular}{|c|c|c|c|c|c|}
\hline $\mathrm{T}_{\mathrm{a}} \min <\mathrm{T}_{\mathrm{c}}-\mathrm{x}<\mathrm{T}_{\mathrm{a}} \max$ & false & true & true & false & true \\
\hline $\mathbf{T}_{\mathrm{c}}-\mathbf{y}$ & 1.247 & 0,553 & 0,533 & 1.233 & 0,631 \\
\hline $\begin{array}{l}\mathrm{T}_{\mathrm{a}} \min <\mathrm{T}_{\mathrm{c}}-\mathrm{y}<\mathrm{T}_{\mathrm{a}} \\
\max \end{array}$ & false & true & true & false & true \\
\hline
\end{tabular}

Sumber: Hasil Analisis Penulis

Hasil simulasi struktur terhadap beban gempa seperti pada Tabel 3, Tanpa dinding geser, struktur SRPMK kurang kaku dalam menerima beban lateral gempa dimana waktu getar struktur masih lebih tinggi dari batas waktu getar yang diijinkan yang juga terjadi pada layout-3 untuk waktu getar gempa arah sumbu-Y, hal ini disebabkan karena pemasangan dinding geser hanya pada sumbu-X saja sehingga tidak ada perkuatan lateral pada sumbu-Y. Perkuatan lateral pada layout-3 hanya terjadi pada sumbu-X saja sehingga waktu getar sumbu$X$ lebih kecil dari waktu getar minimum yang dipersyaratkan mengindikasikan bangunan sangat kaku. Sementara untuk melihat efektifitas dinding geser terhadap waktu getar struktur ditunjukkan pada Tabel 4 berikut:

Tabel 4. Efektifitas Dinding Geser Terhadap Waktu Getar Struktur

\begin{tabular}{cccc}
\hline Model & $\begin{array}{c}\text { T1 } \\
\text { (detik) }\end{array}$ & $\begin{array}{c}\text { Tmaks } \\
\text { (detik) }\end{array}$ & $\begin{array}{c}\text { Penurunan T } \\
(\mathbf{\%})\end{array}$ \\
\hline SRPM & 1,247 & 1,140 & - \\
\hline Layout 1 & 0,553 & 0,741 & 55,65 \\
\hline Layout 2 & 0,536 & 0,741 & 57,02 \\
\hline Layout 3 & 1,233 & 0,741 & 1,12 \\
\hline Layout 4 & 0,631 & 0,741 & 49,40 \\
\hline
\end{tabular}

Efektifitas dinding geser pada Tabel 4 memperlihatkan bahwa pola penempatan dinding geser dalam menambah kekakuan struktur SRPM terhadap beban lateral gempa yaitu antara 50\% hingga $57 \%$. Terkecuali pada layout-3, efektifitas dinding geser dalam menambah kekakuan lateral Gedung berkisar 1\% saja. Hal tersebut juga karena posisi dinding geser yang hanya terpasang pada salah satu sumbu Gedung saja menyebabkan kekakuan lateral Gedung yang tidak sama antara kedua sumbu yaitu kekakuan Gedung di sumbu-X jauh lebih tinggi dari kekauan Gedung pada sumbu-Y sehingga memberikan periode getar fundamental (T1) yang tetap tinggi dan nilainya hampir sama dengan periode fundamental Gedung SRPM yaitu sekitar $1,2 \mathrm{dtk}$.

\section{Partisipasi Massa}

Partisipasi massa yang tercapai dari ragam kombinasi telah mencapai $90 \%$ dari seluruh model struktur sehingga ragam kombinasi telah memenuhi ketentuan analisa ragam. Hasil model ditunjukkan pada Gambar 4.

Gaya Geser Dasar ( $V)$

Kontrol gaya geser dasar $(\mathrm{V})$ untuk setiap model telah memenuhi kriteria seperti pada Tabel 5:

Tabel 5. Kontrol gaya geser dasar $(V)$

\begin{tabular}{|c|c|c|c|c|c|}
\hline $\begin{array}{l}\text { Waktu Getar } \\
\text { (detik) }\end{array}$ & $\begin{array}{c}\text { SRPMK } \\
(\mathbf{k N})\end{array}$ & $\begin{array}{c}\text { Layout- } \\
1 \\
(k N)\end{array}$ & $\begin{array}{c}\text { Layout- } \\
2 \\
(k N)\end{array}$ & $\begin{array}{c}\text { Layout- } \\
3 \\
(k N)\end{array}$ & $\begin{array}{c}\text { Layout } \\
4 \\
(k N)\end{array}$ \\
\hline $85 \%$ V Statik & 3529,82 & 7260,88 & 7260,88 & 6515,54 & 7260,88 \\
\hline
\end{tabular}


TECHNO: Vol. 08 ( 02) Oktober 2019

\begin{tabular}{lllccccc}
\hline $\mathbf{V}_{\mathbf{x}}$ Dinamik & & 3530,54 & 7260,28 & 7262,01 & 7258,58 & 7258,35 \\
\hline $\begin{array}{l}85 \% \quad \mathbf{V} \text { Statik } \\
\text { Dinamik }\end{array}$ & $\mathbf{\mathbf { V } _ { \mathbf { x } }}$ & True & True & True & True & True \\
\hline $\mathbf{V}_{\mathbf{y}}$ Dinamik & & & 3529,21 & 7258,49 & 7263,19 & 6516,66 & 7260,84 \\
\hline $\begin{array}{l}\mathbf{8 5} \% \mathbf{V} \text { Statik } \\
\text { Dinamik }\end{array}$ & $=<$ & $\mathbf{V}_{\mathbf{y}}$ & true & true & true & true & true \\
\hline
\end{tabular}
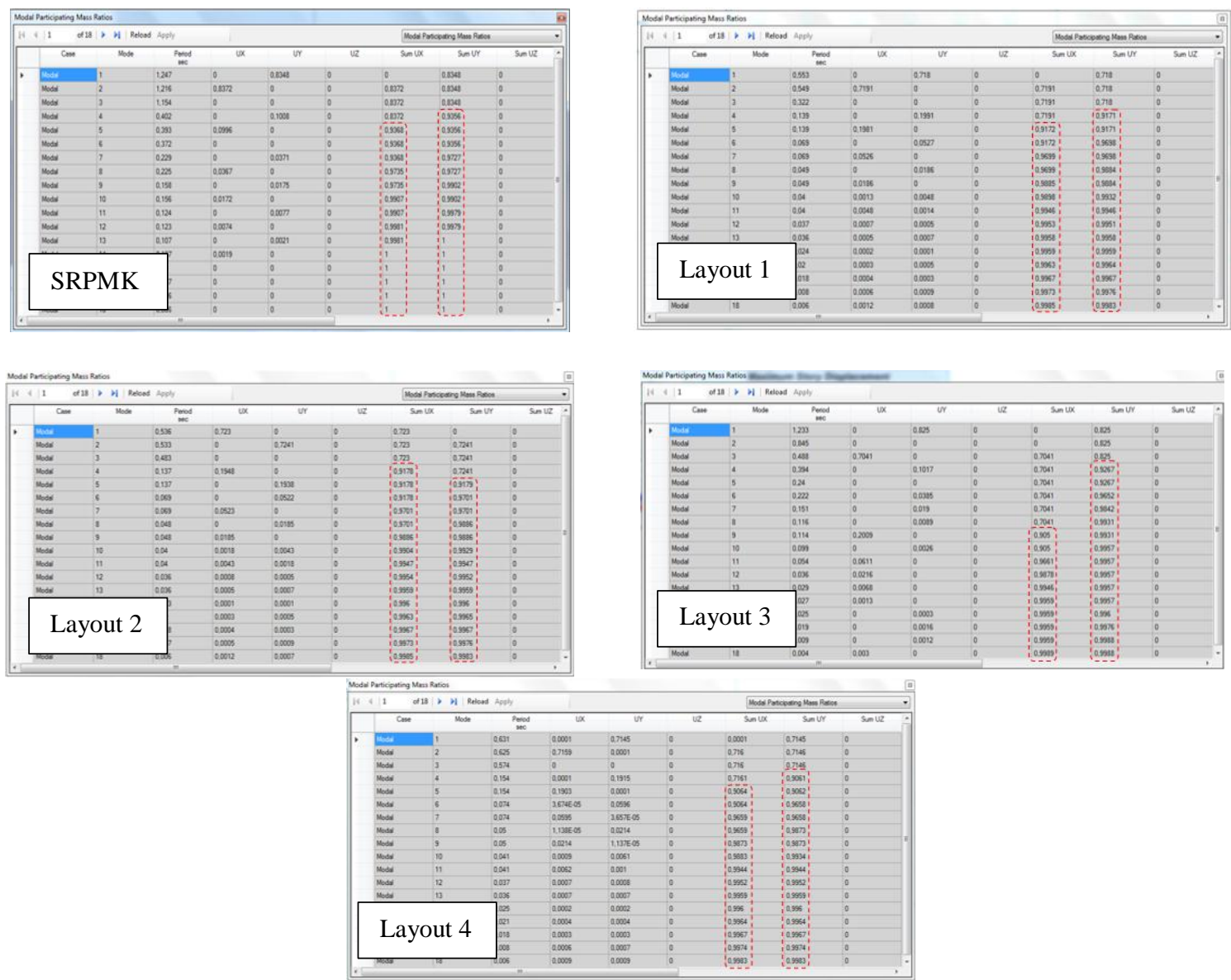

Gambar 4. Output kontrol partisipasi massa

\section{Simpangan Antar Lantai ( $\square)$}

Simpangan gedung akibat beban lateral gempa menunjukkan pola yang serupa yaitu simpangan terbesar terjadi pada bagian tengah ketinggian gedung, bukan pada puncak gedung. Hal tersebut akibat interaksi beban lateral gempa yang memberi dorongan sehingga timbul eksentrisitas pada beban gravitasi struktur. Dari seluruh model struktur hanya layout-3 yang menghasilkan simpangan melampaui batas izin pada kombinasi beban gempa arah-Y. Pola simpangan ditampilkan pada Gambar 5. 
Nurul Anggraini Usmat I., Imran Imran., Mufti A. Sultan. shear wall, gempa, sistem ganda
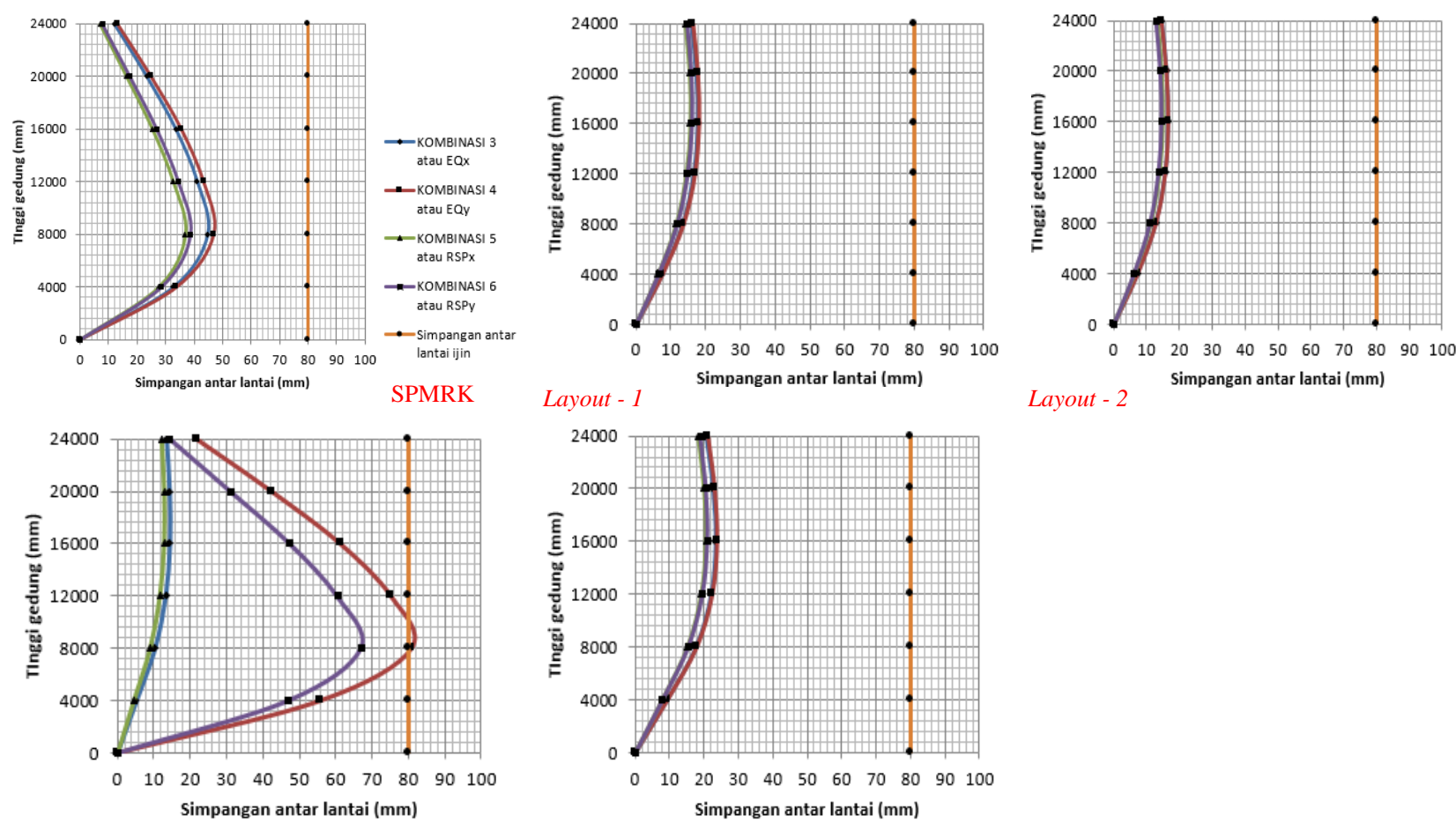

Layout - 2

Simpangan antar lantai $(\mathrm{mm})$

Layout - 3

Layout - 4

Gambar 5. Simpangan antar lantai

\section{Sistem Struktur}

Struktur sistem ganda setelah pemasangan dinding geser sebagai elemen perkuatan penahan lateral terhadap beban gempa dapat ditunjukkan pada Tabel 6 hingga Tabel 9 berikut:

Tabel 6. Sistem ganda pada layout-1

\begin{tabular}{|c|c|c|c|c|c|c|c|c|}
\hline \multirow{3}{*}{$\begin{array}{l}\text { Kombinasi } \\
\text { Pembebanan }\end{array}$} & \multicolumn{4}{|c|}{ Gaya Reaksi (kN) } & \multicolumn{4}{|c|}{ Persentasi Interaksi (\%) } \\
\hline & \multicolumn{2}{|c|}{ FX } & \multicolumn{2}{|c|}{ FY } & \multicolumn{2}{|c|}{ FX } & \multicolumn{2}{|c|}{ FY } \\
\hline & SRPM & SW & SRPM & SW & SRPM & SW & SRPM & SW \\
\hline KOMBINASI 3 & 742,45 & 2155,46 & & & 25,62 & 74,38 & & \\
\hline KOMBINASI 4 & & & 757,05 & 2170,15 & & & 25,86 & 74,14 \\
\hline KOMBINASI 5 & 640,56 & 1843,54 & & & 25,79 & 74,21 & & \\
\hline KOMBINASI 6 & & & 671,97 & 1855,78 & & & 26,58 & 73,42 \\
\hline
\end{tabular}

Tabel 7. Sistem ganda pada layout-2

\begin{tabular}{|c|c|c|c|c|c|c|c|c|}
\hline \multirow{3}{*}{$\begin{array}{l}\text { Kombinasi } \\
\text { Pembebanan }\end{array}$} & \multicolumn{4}{|c|}{ Gaya Reaksi (kN) } & \multicolumn{4}{|c|}{ Persentasi Interaksi (\%) } \\
\hline & \multicolumn{2}{|c|}{ FX } & \multicolumn{2}{|c|}{ FY } & \multicolumn{2}{|c|}{ FX } & \multicolumn{2}{|c|}{ FY } \\
\hline & SRPM & SW & SRPM & $S W$ & SRPM & $S W$ & SRPM & $S W$ \\
\hline KOMBINASI 3 & 723,79 & 2120,34 & & & 25,45 & 74,55 & & \\
\hline KOMBINASI 4 & & & 687,22 & 2120,02 & & & 24,48 & 75,52 \\
\hline KOMBINASI 5 & 640,76 & 1805,28 & & & 26,20 & 73,80 & & \\
\hline KOMBINASI 6 & & & 625,27 & 1805,11 & & & 25,73 & 74,27 \\
\hline
\end{tabular}


Tabel 8. Sistem ganda pada layout-3

\begin{tabular}{ccccccccc}
\hline \multirow{2}{*}{$\begin{array}{c}\text { Kombinasi } \\
\text { Pembebanan }\end{array}$} & \multicolumn{3}{c}{ Gaya Reaksi (kN) } & \multicolumn{4}{c}{ Persentasi Interaksi (\%) } \\
\cline { 2 - 9 } & \multicolumn{2}{c}{ FX } & \multicolumn{2}{c}{ FY } & FX & \multicolumn{2}{c}{ FY } \\
\hline KOMBINASI 3 & 513,90 & 2670,44 & & & 16,14 & 83,86 & & \\
\hline KOMBINASI 4 & & & 4766,31 & 1650,71 & & & 74,28 & 25,72 \\
\hline KOMBINASI 5 & 464,85 & 2290,38 & & & 16,87 & 83,13 & & \\
\hline KOMBINASI 6 & & & 4055,36 & 1403,32 & & & 74,29 & 25,71 \\
\hline
\end{tabular}

Tabel 9. Sistem ganda pada layout-4

\begin{tabular}{|c|c|c|c|c|c|c|c|c|}
\hline \multirow[t]{3}{*}{ V } & \multicolumn{4}{|c|}{ Gaya Reaksi (kN) } & \multicolumn{4}{|c|}{ Persentasi Interaksi (\%) } \\
\hline & \multicolumn{2}{|c|}{ FX } & \multicolumn{2}{|c|}{ FY } & \multicolumn{2}{|c|}{ FX } & \multicolumn{2}{|c|}{ FY } \\
\hline & SRPM & $S W$ & SRPM & SW & SRPM & $S W$ & SRPM & $S W$ \\
\hline KOMBINASI 3 & 751,07 & 2511,47 & & & 23,02 & 76,98 & & \\
\hline KOMBINASI 4 & & & 733,67 & 2522,07 & & & 22,53 & 77,47 \\
\hline KOMBINASI 5 & 659,38 & 2141,93 & & & 23,54 & 76,46 & & \\
\hline KOMBINASI 6 & & & 651,77 & 2151,98 & & & 23,25 & 76,75 \\
\hline
\end{tabular}

Dari 4 model, layout 1, 2, 3 dan 4 setelah pemasangan dinding geser sebagai elemen perkuatan penahan lateral terhadap beban gempa memenuhi sebagai struktur sistem ganda sedangkan pada layout-3 tidak sepenuhnya memenuhi sebagai struktur sistem ganda karena interaksi antara elemen frame dengan dinding geser tidak memenuhi proporsional. Pada simulasi gempa arah-X baik statis maupun dinamik, elemen portal pada model layout-3 hanya menahan kurang dari $17 \%$ gaya geser gempa.

\section{KESIMPULAN}

Berdasarkan hasil analisa waktu getar struktur, nilai simpangan dan nilai presentase masingmasing layout shear wall, shear wall layout 2 yaitu shear wall yang diletakkan simetris sumbu-XY mendekati pusat massa dinilai paling optimum dibandingkan pemodelan layout shear wall yang lainnya.

\section{DAFTAR PUSTAKA}

Andalas, G., Suyadi, S., \& Husni, H. R. (2016). Analisis Layout Shearwall Terhadap Perilaku Struktur Gedung. Jurnal Rekayasa Sipil Dan Desain, 4(3), 491-502.

Astuti, P. (2016). Pengaruh Penambahan Dinding Geser (Shear Wall) pada Waktu Getar Alami Fundamental Struktur Gedung. Semesta Teknika, 18(2), 140-146.

Baehaki, B., Kuncoro, H. B. B., \& Dahlia, P. (2019). PENGARUH LETAK SHEAR WALL PADA GEDUNG TIDAK BERATURAN TERHADAP NILAI SIMPANGAN DENGAN ANALISA RESPONS SPEKTRUM (Studi Kasus: Apartemen di Cimanggis, Depok). Jurnal Fondasi, 8(1). 
Nurul Anggraini Usmat I., Imran Imran., Mufti A. Sultan. shear wall, gempa, sistem ganda

Badan Standarisasi Nasional. (2012). Tata Cara Perencanaan Ketahanan Gempa untuk Struktur Bangunan Gedung dan Non Gedung. SNI 1726-2012. Jakarta. BSN

Badan Standarisasi Nasional. (2013). Beban Minimum untuk Perancangan Bangunan Gedung dan Struktur Lain. SNI 1727-2013. Jakarta. BSN

Badan Standarisasi Nasional. (2013). Persyaratan Beton Struktural untuk Bangunan Gedung. SNI 2847-2013. Jakarta. BSN

Fadli, MH. (2015). Aplikasi ETABS pada Perancangan Gedung 15 Lantai dengan Struktur Beton Bertulang menggunakan Sistem Ganda sebagai Penahan Beban Gempa sesuai SNI 1726-2012 di http://scribd.com (akses 14 November 2018)

Hasan, A., \& Astira, I. F. (2013). Analisis Perbandingan Simpangan Lateral Bangunan Tinggi dengan Variasi Bentuk dan Posisi Dinding Geser. Studi Kasus: Proyek Apartemen The Royale Springhill Residences. Journal of Civil and Environmental Engineering, 1(1).

Kusuma, Y. N. (2018). STUDI BENTUK DAN LAYOUT DINDING GESER (SHEAR WALL) TERHADAP PERILAKU STRUKTUR GEDUNG BERTINGKAT. KURVA S JURNAL MAHASISWA, 1(1), 706-720.

Majore, B. O., Wallah, S. E., \& Dapas, S. O. (2015). STUDI PERBANDINGAN RESPONS DINAMIK BANGUNAN BERTINGKAT BANYAK DENGAN VARIASI TATA LETAK DINDING GESER. JURNAL SIPIL STATIK, 3(6).

Mangoda, N. Z., Sultan, M. A., \& Imran, I. (2019). EVALUASI KINERJIA GEDUNG BETON BERTULANG DENGAN METODE PUSHOVER (Studi Kasus Bangunan Gedung di Ternate). SIPIL SAINS, 9(17).

Schueller, W. (1977). High-rise building structures. John Wiley \& Sons.

Sultan, M. A. (2017). Evaluasi Struktur Beton Bertulang Tahan Gempa Dengan Analisa Pushover. SIPIL SAINS, 6(11). 